raczej łagodne przejście. Chrześcijaństwo, chociaż formalnie odcięło się całkowicie od pogaństwa, to jednak wiele elementów od niego przejęło, wypełniając je nową treścią.

Autora niniejszej publikacji należy również pochwalić za solidność badawczą. Troszczy się o jasność i przejrzystość swoich wywodów, co przejawia się nawet w takich detalach, jak podkreślanie kluczowych słów przy analizie źródłowego tekstu. Świadczy o tym też m.in. szeroko opracowana baza bibliograficzna i indeksy. Chociaż wydaje się, że Salustiusza, którego dokładnie cytuje św. Hieronim w Vita Hilarionis i św. Augustyn w De civitate Dei, jak zaznacza sam Autor (s. 24), należało również umieścić w źródłach klasycznych. Można było też w zestawieniu bibliograficznym uwzględnić polską pozycję obszernie traktującą o sztuce retoryki (por. M. Korolko, Sztuka retoryki. Przewodnik encyklopedyczny, Warszawa 1990). W pracy dostrzega się też drobne niedociągnięcia drukarskie (np. na s. 24 jest „De coniuratine” zamiast „De coniuratione”, czy też na s. 103 jest „upadkowu” zamiast „upadkowi”). Te potknięcia w niczym jednak nie umniejszają jej wartości.

Pozostaje jeszcze wyrazić żal, że tekst łaciński nie jest tłumaczony na język polski. Przeciętny odbiorca nie zawsze może zrozumieć całość wypowiedzi hagiografa, opierając się tylko na komentarzu Autora. W ten sposób wydaje się, że Autor zwraca się tylko do nielicznego grona ludzi znających łacinę. Może też dlatego książka została wydana w tak małym nakładzie (380 egzemplarzy)? A szkoda, bo warta jest tego, aby udostępnić ją szerszemu gronu czytelników, tym bardziej, że kultura antyczna w Polsce jest wciąż jeszcze bardzo mało znana.

Niniejsza praca powinna stać się wyzwaniem i inspiracją dla współczesnych propagatorów nauki Jezusa Chrystusa. Skoro wczesnochrześcijańscy hagiografowie, patrząc z perspektywy historycznej, zapewnili sobie tak wielką poczytność dzięki zastosowaniu sztuki retorycznej, to może warto szerzej zaznajomić się z jej prawidłami. Byłyby na pewno przydatne dla wszystkich mówców, szczególnie tych z ambon kościelnych.

Ks. Józef Figiel - Lublin

Vincent DESPREZ OSB, Początki monastycyzmu. Dzieje monastycyzmu chrześcijańskiego do Soboru Efeskiego (431), I-II, przedmowa O. Pierre Miquel OSB, przekład Janina Dembska, redakcja naukowa ks. Marek Starowieyski, „Źródła Monastyczne” 21-22, Kraków-Tyniec 1999, Wydawnictwo Benedyktynów, ss. 430 (I), 414 (II).

Seria wydawnicza „Źródła Monastyczne”, działająca stosunkowo od niedawna, bo od 1993 roku, raz po raz potwierdza swoją aktywność wydawniczą. Świadczy o tym chociażby ukazanie się niniejszej książki, która stanowi już 21 
i 22 tom tejże serii. Autorem jest francuski benedyktyn O. Vincent Desprez z opactwa w Ligugé, gdzie prowadzi wykłady z historii monastycyzmu starożytnego i Ojców greckich. Do jego najważniejszych dotychczasowych osiągnięć naukowych należy m.in. edycja i przekład dzieł Pseudo-Makarego dla „Sources Chrétiennes" (SCh 275). Na gruncie polskim dał się poznać jako autor obszernego wstępu do 11 tomu „Źródeł Monastycznych”. Ponadto jest autorem artykułu znajdującego się w pracy zbiorowej, będącej owocem obrad międzynarodowego sympozjum zorganizowanego w Tyńcu i Krakowie w dniach 16-19 listopada 1994 r. przez benedyktynów tynieckich i krakowski $\mathrm{PAT}^{10}$.

Prezentowana książka zawiera cykl wykładów z historii starożytnego monastycyzmu wschodniego, wygłaszanych od 1975 r. dla nowicjatu klasztoru w Ligugé oraz na innych kursach. Publikowano je już wcześniej w formie odcinków od 1980 r. w „Lettres de Ligugé”, ale w całości, uzupełnione o najnowsze źródła, ukazały się dopiero w 1998 r. jako 72 tom serii „Spiritualité Orientale" $"$. Wydanie polskie jest tłumaczeniem tego właśnie dzieła.

Całość materiału Autor podzielił na 15 rozdziałów. W pierwszym z nich zwraca uwagę, że starożytny monastycyzm miał już w pewnym sensie swoich poprzedników, bo przecież takie jego cechy, jak np. szczególne poświęcenie się Bogu, asceza czy też doświadczenie pustyni, znajdujemy już u starotestamentalnych patriarchów i proroków. Niemałe znaczenie, jak słusznie podkreślono, ma też tutaj postać Filona z Aleksandrii, który propagował kontemplacyjny styl życia. Najwięcej uwagi poświęca jednak Autor celibatowi wykazując, że Stary Testament i świat pogański dostarczają pojedyncze przykłady wstrzemięźliwości seksualnej ze względów religijnych i czynników motywujących ją. Konkluduje jednak, że ,wezwanie ewangeliczne, aby wszystko zostawić i pójść za Chrystusem, opiera się na fundamentach przekraczających wszelkie przewidywania" (I, s. 66).

W kolejnym rozdziale O. Desprez zwraca uwagę czytelnika na istnienie żydowskich grup ascetycznych: esseńczyków i terapeutów. Z tymi pierwszymi utożsamia też wspólnotę z Qumran. Wykazuje, że ich praktyki ascetyczne miały z pewnością jakiś pośredni lub nawet bezpośredni wpływ na życie monastyczne, skoro później odwoływali się do nich niekiedy pisarze monastyczni, ale zarazem podkreśla, że nadmierny idealizm terapeutów oraz partykularyzm esseńczyków zupełnie kontrastują z życiem monastycznym.

${ }^{9}$ Por. V. Desprez, Cenobityzm pachomiański, w: Pachomiana Latina, tłum. A. Bober W. Miliszkiewicz - M. Starowieyski, Kraków 1996, 15-82.

${ }^{10}$ Por. V. Desprez, Le monachisme lérinien d'Honorat à Cesaire d'Arles (400-543). Lecture de quelques textes, w: The Spirituality of Ancient Monasticism. Acts of the International Colloquium held in Cracow-Tyniec, 16-19 $9^{\text {th }}$ November 1994, ed. by M. Starowieyski, Tyniec-Cracow 1994, 197-226.

${ }^{11}$ Por. V. Desprez, Le monachisme primitif. Des origines jusqu'au concile d'Éphèse, Abbaye de Bellefontaine 1998. 
W rozdziale III przechodzi Autor do Nowego Testamentu stawiając tezę, że tutaj leżą właściwe źródła monastycyzmu. Pokrótce przedstawia postaci Jana Chrzciciela i Najświętszej Maryi Panny, które staną się wzorami dla mnichów, aby następnie pokazać, że prawdziwy początek chrześcijańskiego życia zakonnego tkwi w Jezusie Chrystusie, Synu Bożym. Wezwanie do pójścia za Nim stanie się prawdziwą inspiracją najpierw dla Apostołów, św. Pawła i całej pierwszej wspólnoty chrześcijańskiej w Jerozolimie, a następnie dla monastycyzmu. Wyrzeczenie się majątku, posłuszeństwo i celibat będą konsekwencją naśladowania Chrystusa. Na kanwie tych rozważań O. Desprez dokonuje też spostrzeżenia, że tylko ewangeliczna rada dziewictwa (celibatu) została wyraźnie sformułowana na kartach Nowego Testamentu, natomiast dwie pozostałe, chociaż harmonizują z duchem ewangelicznym, nie zostały wprost określone.

Kolejny rozdział ukazuje proces rozwoju ascezy chrześcijańskiej w II i III wieku, która stanowi najstarszą formę życia zakonnego w Kościele. Przejawiała się ona przede wszystkim $\mathrm{w}$ rezygnacji $\mathrm{z}$ małżeństwa, której towarzyszyło umartwienie cielesne, ubóstwo, post, samotność, modlitwa i lektura Pisma Świętego. Autor zwraca uwagę, że asceza, pod wpływem dualizmu platońskiego i gnostyckiego, nie ustrzegła się jednak różnych wypaczeń, których przykładem jest enkratyzm, odrzucający małżeństwo i niektóre pokarmy. Te kryzysy przyczyniły się jednak do skrystalizowania się doktryny wstrzemięźliwości i ewangelicznego wyrzeczenia, którą na kartach swoich pism wyrażą tacy teolodzy III wieku, jak Klemens Aleksandryjski, Orygenes, Tertulian, św. Cyprian czy też św. Metody z Olimpu.

$\mathrm{Z}$ tej ascezy powstanie nowa forma - anachoretyzm, charakteryzująca się zerwaniem ze społeczeństwem, której symbolem jest św. Antoni Pustelnik. Autor kreśli jego wizerunek w V rozdziale, uwzględniając chronologię, kontekst geograficzny i społeczny, a przede wszystkim analizując dostępne źródła, z których podstawowymi są Vita Antonii św. Atanazego z Aleksandrii i Listy samego Antoniego. Porównując te dwa dzieła O. Desprez zauważa, że Antoni został w Żywocie ukazany jako asceta pozostający w całkowitej łączności z Kościołem, natomiast w Listach jawi się jako teolog i kontemplatyk, u którego można dopatrzyć się wpływów orygenizmu. Jednak jego żarliwość i umiłowanie Chrystusa pozwala słusznie widzieć w nim ojca anachoretyzmu.

Rozdział VI ukazuje kolejną wielką postać monastycyzmu - św. Pachomiusza, który tworzył wspólnoty mnichów żyjących w klasztorze sub regula vel abbate, co zapoczątkowało nową formę życia mniszego - cenobityzm. Niewątpliwy udział mieli w tym też jego współpracownicy i następcy - Teodor i Horsiesi. Autor przedstawia życie, działalność i rozwój dzieła Pachomiusza, analizując dostępne biografie świętego, ułożoną przez niego Regułę, a także Regulamin autorstwa Horsiesiego, oraz listy i katechezy wszystkich trzech wielkich męzów cenobityzmu. Ukazują one Pachomiusza przede wszystkim 
jako wielkiego ascetę, ojca duchownego i wspaniałego organizatora, a także codzienne życie mnichów i zasady, które przyświecały życiu wspólnoty.

Ostatni rozdział I tomu poświęcony został anachoretom z Dolnego Egiptu, znanym powszechnie jako Ojcowie Pustyni. Autor omawia pokrótce trzy główne siedziby anachoretów: Nitrię, Cele i Sketis, wymieniając przy tym najważniejszych przedstawicieli i doniosłe wydarzenia związane z tymi miejscami. Następnie zajmuje się instytucjami, charyzmatami i pismami anachoretów, zwracając szczególnie uwagę na doktrynę Ojców Pustyni. Dokonane zaś analizy pozwoliły mu stwierdzić, że Ojcowie Pustyni, mimo swej prostoty, potrafili stworzyć wspaniałą literaturę, w której przejawia się mądrość inspirowana doświadczeniem oraz mocna i prawdziwie chrześcijańska duchowość.

Z Egiptu przenosi Autor czytelnika na teren Azji Mniejszej i Syrii (rozdz. VIII), po to by ukazać panoramę ruchów monastycznych, które tam się rozwinęły. Jak zauważa - wiele $\mathrm{z}$ nich nie ustrzegło się błędów, poprzez nadmierne eksponowanie ascezy (eustacjanie i aerianie), czy też mistycyzmu (mesalianie). Tę panoramę tworzą również biskupi i teoretycy monastycyzmu, jak Bazyli z Ancyry, św. Grzegorz z Nazjanzu, św. Grzegorz z Nyssy, Amfiloch z Ikonium i św. Jan Chryzostom. Autor przedstawia krótko ich poglądy na życie monastyczne, stwierdzając, że uwidacznia się w nich troska o właściwe motywacje podejmowania drogi mniszej, choć w niektórych przypadkach można dostrzec wpływy nieortodoksyjnych grup ascetycznych.

W rozdziale IX omawia O. Desprez życie i twórczość ascetyczną św. Bazylego, bpa Cezarei Kapadockiej, oraz jego doktrynę ascetyczną. Bazyli kładł szczególny nacisk nie tyle na wyrzeczenie i charyzmaty, co na miłość Boga i bliźniego, która wyraża się m.in. we wspólnotowym życiu, wstrzemięźliwości, pracy, modlitwie, aktywności i posłuszeństwie. Autor podkreśla fakt, że Bazyli pojmował wstrzemięźliwość nie jako stronienie od pokarmów, ale jako wyrzeczenie się rzeczy przyjemnych i wszelkich namiętności; przytaczając zaś szereg jego wskazówek odnośnie przyjmowania kandydatów, wytycznych dla przełożonych, czy też korzystania ze środków medycznych, ukazuje jego troskę o dobro wspólnoty monastycznej.

Kolejny rozdział $(\mathrm{X})$ dotyczy jednego $\mathrm{z}$ najwybitniejszych pisarzy monastycznych - Ewagriusza z Pontu. Autor przedstawia krótko jego życiorys, by przejść do omówienia jego dzieł ascetycznych i ważnych elementów doktrynalnych. Jego poglądy filozoficzno-teologiczne miały bowiem niebagatelny wpływ na całość koncepcji życia ascetycznego, która w dalszej kolejności zostanie szeroko omówiona. Na tle swojej nauki Ewagriusz jawi się jako świetny teolog i znawca problematyki ascetycznej. Jego jasne analizy psychologiczne, klasyfikacja namiętności, a także uczciwość moralna i umiłowanie Boga słusznie stawiają go w rzędzie największych umysłów monastycyzmu. Jednakże, zdaniem O. Despreza, Ewagriusz zbyt ryzykownie łączył filozofię, Biblię i doświadczenie ascetyczne. Wydaje się jednak, że Autor formułując taką opinię, 
sugeruje się chyba zanadto oceną francuskiego uczonego A. Guillaumonta, jak słusznie podkreślono w nocie odredakcyjnej (II, s. 114, przypis 115).

Dalsze strony swojej pracy (rozdz. XI) poświęcił Autor innej wielkiej postaci monastycyzmu - Makaremu-Symeonowi, zwanemu też Pseudo-Makarym, ze względu na przypisywanie jego dzieł Makaremu Egipcjaninowi. Najpierw czytelnik zostaje zaznajomiony z ogólnymi informacjami na temat działalności tego mnicha i wprowadzony w toczące się spory odnośnie jego biografii, po czym następuje ukazanie jego nauki na temat wspólnoty, modlitwy, walki duchowej oraz doświadczenia grzechu i przeobrażającej łaski. Uderza w niej duża znajomość Pisma św. i głębia komentarzy. Całość tchnie wielką żarliwością i umiłowaniem Boga. Ta nauka jest, zdaniem Autora, wciąż aktualna, chociaż niektóre jego tezy jako mesaliańskie, zostały odrzucone najpierw przez synod w Konstantynopolu (428), a następnie przez Sobór Efeski (431).

Rozdział XII ukazuje rozwój monastycyzmu na terenach obszaru języka syryjskiego, a więc trzech prowincji: Syrii, Osrhoene i Adiabene. Autor sygnalizuje, że asceza rozwijała się tutaj już od II wieku, ale w pełni ukształtowała się dopiero pod koniec IV wieku. Jej osiągnięcia zostaną udostępnione czytelnikowi na przykładzie twórczości Afrahata, św. Efrema oraz zbioru 30 homilii zwanych Liber graduum, a napisanych przez anonimowego autora. Obraz życia ascetycznego w wydaniu Afrahata budowany jest na życiu chrześcijańskim opartym na miłości. Efrem, który jest świadkiem trwałego nurtu ascetycznego w łonie Kościoła syryjskiego, wiąże ascezę z teologią i eklezjologią. Fundamentem ascezy jest dla niego Pismo Święte. Liber graduum natomiast łączy surową ascezę z duchem misyjnym i pobożnością chrystologiczną.

Dokonawszy prezentacji monastycyzmu wschodniego, Autor przedstawia z kolei początki życia monastycznego na Zachodzie (rozdz. XIII), zaznaczając równocześnie, że do jego rozwoju przyczyniła się asceza praktykowana przez trzy pierwsze wieki chrześcijaństwa oraz idee monastycyzmu przejęte ze Wschodu, które zostały przeszczepione na grunt łaciński głównie przez św. Atanazego i św. Hieronima. Te dwie postacie poprzedzają całą plejadę ascetów rozpoczynając od mnichów działających w Galii, jak św. Honorat i Jan Kasjan, poprzez monastycyzm afrykański ze św. Augustynem i Fulgencjuszem z Ruspe, aż po życie zakonne w Hiszpanii. Najwięcej miejsca poświęcił Autor św. Augustynowi, twórcy reguły zakonnej, który swoją doktrynę monastyczną oparł na komunii serc i wspólnocie dóbr oraz klasycznych środkach ascezy, klasztor zaś umiejscowił w samym centrum Kościoła. Wydaje się, że Autor zbyt mało miejsca przyznał tu Janowi Kasjanowi, który przecież usystematyzował naukę ascetyczną w jedną całość i stworzył wszechstronną naukę o modlitwie.

Osobny kolejny rozdział (XIV) poświęcony został św. Marcinowi - mnichowi, fundatorowi i biskupowi. Autor przedstawił w nim najpierw trudności związane z chronologią dotyczącą życia św. Marcina, a następnie ukazał go 
w każdej z wyżej wymienionych funkcji. Konkludując zaś podkreślił, że święty ten jest postacią oryginalną i zarazem kontrowersyjną, jednak podstawowe jego cechy jak pokora, żarliwa wiara i służba bliźniemu czynią z niego jedną $\mathrm{z}$ wielkich osobistości zachodniego monastycyzmu.

W ostatnim wreszcie rozdziale (XV) Autor podejmuje kwestię stosunku mnichów do Eucharystii, próbując porównać ich praktyki ze współczesnymi. O. Desprez dochodzi do wniosków, że w świecie mnichów Eucharystia nie zajmowała centralnego miejsca, ponieważ ich pobożność przejawiała się raczej w praktykach ascetycznych, chociaż byli mnisi, którzy autentycznie żyli Eucharystią. Istniały też grupy ascetyczne jak np. mesalianie, które odrzucały nie tylko Eucharystię, ale i inne sakramenty. Z kolei eustacjanie nie stronili od Eucharystii, ale gromadzili się w małych grupach bez obecności kapłana: były to jednak ruchy heretyckie. Konkludując Autor stwierdza, że między tamtą epoką a naszą istnieje jednak fundamentalna zgodność wiary.

Otrzymaliśmy więc wspaniałą książkę, która przybliża te odległe czasy, w których rodził się monastycyzm. Autor snuje swoją opowieść z pasją godną najlepszych tradycji klasztoru w Ligugé, ujawniając przy tym wielką znajomość tematu. Komunikatywność przekazu i wyprowadzanie logicznych wniosków zachęca do lektury tego opracowania i rozbudza ciekawość. Swój udział ma w tym także z pewnością dobrze zredagowany polski przekład. Godną pochwały inicjatywą jest też umieszczenie pod poszczególnymi rozdziałami stosownej bibliografii, która została podzielona tematycznie. Autor zadbał nawet o krótkie streszczenie niektórych ważnych pozycji (np. I, s. 103-104). Nadto redakcja uzupełniła zestaw bibliograficzny o istniejące polskie pozycje i sporządziła indeksy ułatwiające poruszanie się po całości materiału. Dziwi tylko fakt, że nie zamieszczono bibliografii tematycznej w rozdziale III, skoro znajduje się we wszystkich pozostałych. Nie uniknięto też drobnych błędów drukarskich np. jest „naziratu” zamiast „nazireatu” (I, s. 83), czy też „Metz” zamiast „Tetz” (I, s. 275, przypis 275), albo „mysli” zamiast „myśli” (II, s. 92). Trudno jednak dopracować wszystko w sposób doskonały przy takiej rozległości materiału, jaki zawiera to dzieło.

Wartość tej pracy polega też na tym, że Autor swoje wywody potwierdza obszernymi fragmentami dzieł monastycznych, które pozwalają czytelnikowi konfrontować jego tezy z pierwotnym źródłem. Na ich tle wczesnochrześcijańscy asceci jawią się w zupełnie innym świetle. Mimo tego, że wielu z nich nie ustrzegło się tendencji heretyckich, a nawet niektórych nauka została potępiona przez Kościól, jak to np. ma miejsce w przypadku Makarego-Symeona, to jednak promieniuje z nich prawdziwa żarliwość i poświęcenie się Bogu, a ich dorobek ascetyczny jest niepodważalny i nic nie traci ze swej aktualności. Autor wydaje się zwracać uwagę, że pośpieszne streszczenia fragmentów ascetycznych, użycie niezręcznych zwrotów, liczne uogólnienia, jakie miały miejsce w rozpowszechnianiu tekstów, przyczyniły się do ich fałszywego rozumienia. 
Dlatego rodzi się potrzeba ponownego odczytania źródeł ascetycznych w oparciu o najnowszy aparat naukowy.

Czytając pracę O. Despreza ma się wrażenie, że wiele dzisiejszych trendów nawiązuje do starożytnych tendencji. Czyż nie jest tak w przypadku odrzucania instytucjonalnego Kościoła, przedkładania osobistej modlitwy nad Eucharystię, odczytywania tworów własnej wyobraźni za objawienia? Te tezy towarzyszyły działalności heretyków i zostały odrzucone przez Kościół, mimo to odżywają we współczesności, nawet w katolickich ruchach religijnych. Reasumując należy stwierdzić, że wszystkie wymienione zalety decydują o aktualności pracy i przydatności w studiach nad życiem i literaturą ascetyczną czterech pierwszych wieków chrześcijaństwa.

Ks. Józef Figiel - Lublin

\section{Origeniana Septima. Origenes in den Auseinandersetzungen des 4. Jahrhunderts, herausgegeben von W.A. Bienert und U. Kühneweg, Leuven 1999, Bibliotheca Ephemeridum Theologicarum Lovanien- sium CXXXVII, ss. 848.}

Znawcy i miłośnicy patrystyki, a szczególnie specjaliści zajmujący się środowiskiem aleksandryjskim, zwłaszcza postacią i teologią Orygenesa, mają kolejny powód do radości. Ukazał się opasły tom, dokumentujący ostatnie z odbywających się od ponad ćwierć wieku w czteroletnich odstępach międzynarodowych sympozjów, poświęconych wielkiemu teologowi aleksandryjskie$\mathrm{mu}^{1}$. Tym razem ponad 100 badaczy myśli orygeniańskiej z 18 krajów gościło w Niemczech. Obrady konferencji odbywały się w dniach od 25 do 29 sierpnia 1997 roku w pomieszczeniach Akademii Ewangelickiej w zameczku Schönburg w miejscowości Hofgeismar oraz w gmachu Philipps-Universität w Marburgu. Zebrane materiały opublikowała seria wydawnicza „Bibliotheca Ephemeridum Theologicarum Lovaniensium”, która już po raz trzeci podejmuje się wydania „Origenianów”2.

' Kalendarium dotychczasowych „Origenianów” przedstawia się następująco: Montserrat (1973), Bari (1977), Manchester (1981), Innsbruck (1985), Boston (1989), Chantilly (1993).

${ }^{2}$ Nakładem wydawnictwa University Press z Leuven ukazały się materiały z dwóch poprzednich sympozjów: Origeniana Quinta. Papers of the 5th International Origen Congress, Boston College, 14-18 August 1989, ed. R.J. Daly, Leuven 1992; Origeniana Sexta. Origène et la Bible / Origen and the Bible. Actes du Colloquium Origenianum Sextum, Chantilly, 30 août - 3 septembre 1993, ed. G. Dorival - A. Le Boulluec, Leuven 1995. Akta pozostałych kongresów opublikowali: Origeniana. Premier colloque international des études origéniennes (Montserrat, 18-21 septembre 1973), Quaderni di „Vetera Christianorum” 12, ed. H. Crouzel - G. Lomiento - J. Rius-Camps, Bari 1975; Origeniana secunda. Second colloque international des études origéniennes (Bari, 20-23 septembre 1977), ed. H. Crouzel - A. Quacquarelli, Quaderni di „Vetera Christianorum” 15, Roma 